\title{
Effects of management cessation on hoverflies (Diptera: Syrphidae) across Austrian and Swiss mountain meadows
}

\author{
Ronnie Walcher ${ }^{1}$, Raja Imran Hussain ${ }^{1}$, Johannes Karrer ${ }^{1}$, Andreas Bohner ${ }^{2}$, David Brandl ${ }^{1}$, \\ Johann G. Zaller ${ }^{1}$, Arne Arnberger ${ }^{3}$, and Thomas Frank ${ }^{1}$ \\ ${ }^{1}$ Institute of Zoology, University of Natural Resources and Life Sciences Vienna (BOKU), 1180 Vienna, Austria \\ ${ }^{2}$ Agricultural Research and Education Centre Raumberg-Gumpenstein, 8952 Irdning-Donnersbachtal, Austria \\ ${ }^{3}$ Institute of Landscape Development, Recreation and Conservation Planning, \\ University of Natural Resources and Life Sciences Vienna (BOKU), 1180 Vienna, Austria
}

Correspondence: Ronnie Walcher (ronnie.walcher@gmx.at)

Received: 7 April 2020 - Revised: 19 August 2020 - Accepted: 8 September 2020 - Published: 20 October 2020

\begin{abstract}
Extensively managed grasslands, particularly in mountain regions, are considered to be one of the most diverse agroecosystems worldwide. Their decline due to land use abandonment affects the diversity of both plants and associated pollinators. Extensive grasslands constitute an important habitat type and food resource for hoverflies (syrphids); however, not much is known about the effects of abandonment on this important pollinator group. In the present study, we investigated how abandonment affects species richness and the composition of syrphids in mountainous meadows. We recorded the richness of vascular plants, vegetation cover, flower cover and the surrounding landscape to examine whether and how syrphids are affected by plant and landscape parameters. We investigated the species richness, abundance and species composition of syrphids by sweep netting and by using observation plots in 18 semidry meadows across two Austrian regions and one Swiss region. For each region, we selected three meadows abandoned for more than 20 years and three annually mown non-fertilized meadows. Abandonment or mowing had no significant effect on the total number of syrphid species or individuals or on the number of aphidophagous and non-aphidophagous species and individuals. However, the total number of species and the number of non-aphidophagous species significantly increased with the increasing number of plant species. The surrounding landscape and other plant parameters showed no association with the assessed syrphid parameters. Although syrphids were unaffected by abandonment, higher syrphid species numbers in response to a higher plant richness in annual mown meadows suggest that the management of mountain meadows is beneficial in preserving syrphid richness.
\end{abstract}

1

Seminatural grasslands are considered one of the most valuable agroecosystems throughout Central European landscapes and are characterized by a high biodiversity (Chytrý et al., 2015; Habel et al., 2013; Maurer et al., 2006). In particular, extensive management by mowing or grazing is an important management scheme to maintain these habitats of high nature conservation value (Hansson and Fogelfors, 2000; Moog et al., 2002). Most of these grassland habitats have a long history and were maintained by local farm- ers for hay making and animal husbandry over hundreds of years (Chemini and Rizzoli, 2003; Poschlod and WallisDeVries, 2002). Since their conservation relies strongly on human land use activities, they are considered seminatural habitats (Heijcman et al., 2013). Due to a high economical pressure in recent decades, traditional management has become more and more unviable (Hinojosa et al., 2016; McGinlay et al., 2017). Thus, to increase the yield, new agricultural and cultivation techniques were developed which have led to an intensification of grasslands in favorable regions on the one hand and afforestation or abandonment in marginal 
regions on the other hand (Graf et al., 2014; Tasser et al., 2007). Besides economical reasons, ecological factors like slope inclination and accessibility are important drivers for farmers' decisions to cease management especially in mountainous landscapes (Tasser et al., 2007; Rey Benayas et al., 2007; Strijker, 2005). Abandonment has led to an ongoing decline of traditionally managed seminatural meadows, confining them to small patches within the landscape (Graf et al., 2014). Successional processes alter habitat conditions and have been leading to an increase in dominant grass species and the establishment of trees and shrubs on formerly managed meadows (Cremene et al., 2005; Diemer et al., 2001; Galvánek and Lepš, 2008; Tasser and Tappeiner, 2002). Consequently, plant species which demand regular management decline during this succession process (Hülber et al., 2017; Pykälä et al., 2005). Thus, an important research question is how insect populations might respond to changing vegetation characteristics after abandonment.

Generally, the extent of how abandonment affects insects depends very much on the considered insect groups (Bonari et al., 2017; Burel, 1991; Walcher et al., 2017) and can even differ between species within the same taxon (Jovičić et al., 2017). While some insect taxa benefit from the altered structural and environmental conditions in abandoned meadows, e.g., ants (Azcárate and Peco, 2011; Wiezik et al., 2013) and grasshoppers (Baur et al., 2006; Schirmel et al., 2011), recent studies showed detrimental effects of abandonment on pollinators such as butterflies (Öckinger et al., 2006) and bumblebees (Walcher et al., 2017). Until now, the response of hoverflies (syrphids) to the abandonment of extensively managed meadows in mountainous regions has been little studied.

Along with wild bees, syrphids are important pollinators of both wildflowers and crops (Jauker and Wolters, 2008). They may also play a role as pollinators in habitats which are unsuitable, for example, for wild and honey bees (Jauker et al., 2009; Rader et al., 2016). Besides providing important pollination services, hoverfly species whose larvae are aphidophagous contribute strongly to the efficient control of aphid populations (Leroy et al., 2014). Furthermore, hoverflies represent important bioindicators, which makes them an important insect group to study the effects of land use changes (Burgio and Sommagio, 2007).

In a study investigating hoverfly communities in regularly mown and abandoned mountainous grasslands, extensively managed meadows contained a higher number of hoverfly individuals compared to abandoned meadows (Hussain et al., 2017). Furthermore, the study found a positive relationship between flower cover and plant richness with hoverfly abundance. However, it is unclear whether these relationships vary among different regions. Thus, it is important to collect and merge data from several mountainous regions to obtain more generally valid results. Therefore, in the present study, we analyzed the data of three regions including those reported by Hussain et al. (2017). Analogous to their study, we tested the effects of abandonment, vegetation parameters and further surrounding landscape parameters on species richness and the abundance of syrphids in three regions across the Alps. In addition to the former study, here we further distinguished between species whose larvae have an aphidophagous of non-aphidophagous feeding mode. In the present study, we expected a clear response of hoverflies to abandonment due to altered vegetation characteristics, like decreasing plant and flower resources, which in turn are important determinants of hoverfly richness and abundance (Haenke et al., 2009). The surrounding landscape was included in the present study because it was reported to affect the number of hoverflies in grassland ecosystems (e.g., Gittings et al., 2006; Power et al., 2016).

We expected (i) different numbers of hoverfly species and individuals and a different hoverfly species composition between management types. Furthermore, we investigated (ii) whether and how hoverflies are affected by plant richness, flower cover, the cover of the vegetation and the surrounding landscape. Additionally, we investigated (iii) the effects of abandonment and plant and landscape parameters on both aphidophagous and non-aphidophagous hoverflies.

\section{Material and methods}

\subsection{Study regions and sites}

Investigations were carried out in June and August 2015. Altogether, 18 mountainous meadows in the Austrian and Swiss Alps were investigated. Two regions were located in Austria (central Ennstal and Großes Walsertal) and one region in Switzerland (Val Müstair) (Fig. 1). Investigations in the central Ennstal region were carried out in the municipalities of Sankt Gallen, Stainach and Pürgg, in Großes Walsertal in the municipality of Sonntag/Buchboden, and in the Val Müstair region in the municipalities of Valchava, St. Maria and Tschierv. The central Ennstal region is located in the Austrian federal state of Styria ranging from the Gesäuse national park in the east to Grimming mountain in the west. The meadows were situated at altitudes between 690 and $770 \mathrm{~m}$ above sea level (a.s.l.). Großes Walsertal is a biosphere reserve located in the Austrian federal state of Vorarlberg. Meadows were situated at altitudes between 1170 and $1280 \mathrm{~m}$ a.s.l. Val Müstair in the canton of Graubünden is situated in the Eastern Alps of Switzerland near the border with South Tyrol (Italy). Meadows in this region were situated at altitudes between 1740 and $1800 \mathrm{~m}$ a.s.l. Detailed information on the investigated meadows is shown in Table $\mathrm{S} 1$ in the Supplement. Within each region, six south-facing meadows were selected $(n=18)$. Three of the six meadows were annually mown and non-fertilized. The farmers usually mow the meadows from the end of July to the beginning of $\mathrm{Au}-$ gust depending on the annual weather conditions. Due to restricted accessibility with mowing machines, the meadows are mown manually with sickle bar mowers. Three of the six meadows had been abandoned for at least 20 years (Val 


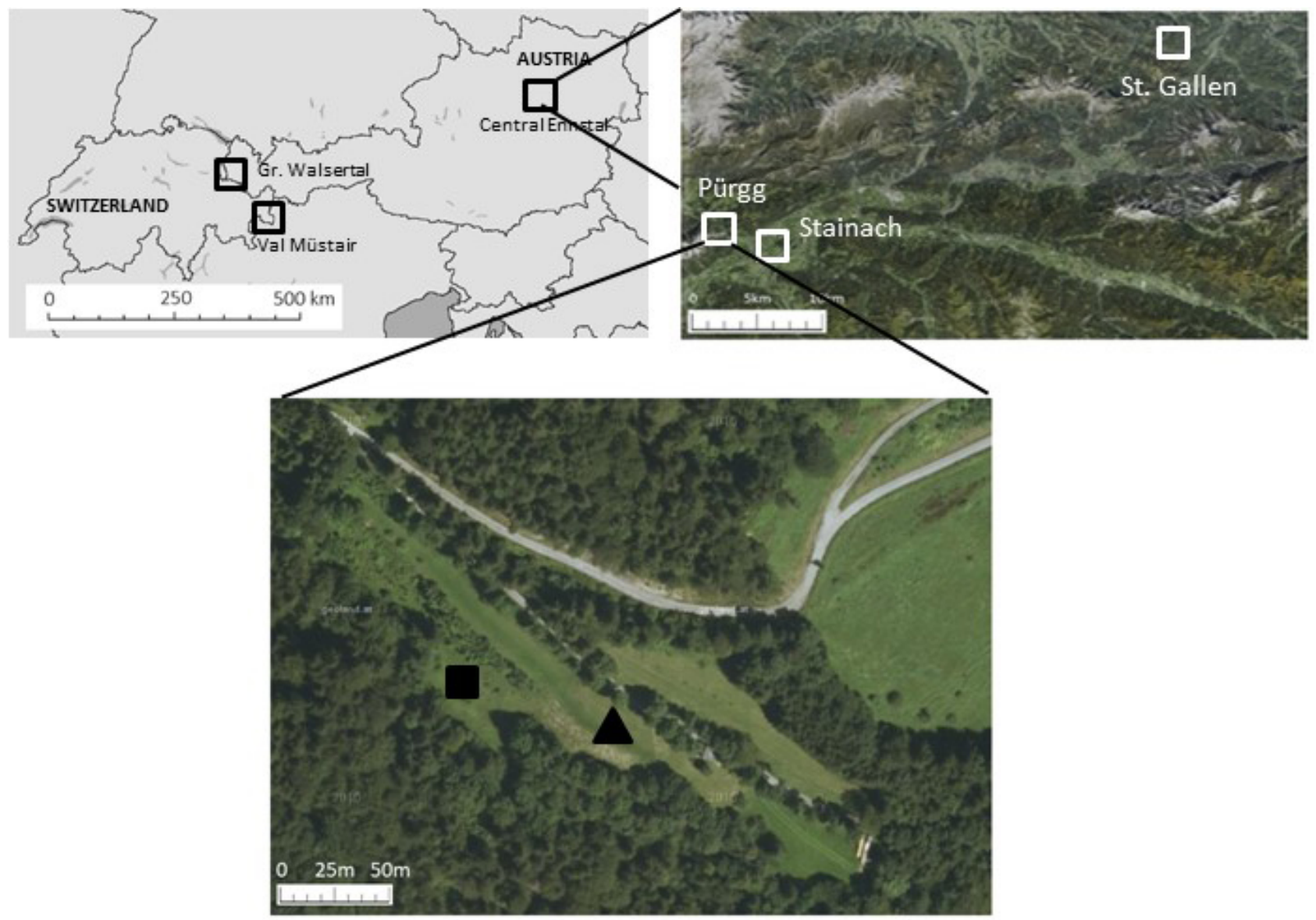

Figure 1. Location of the three study regions (central Ennstal, Großes Walsertal and Val Müstair). Detailed maps are shown for the central Ennstal region with the focus on two meadows in the municipality of Pürgg (the filled square outlines the location of one abandoned meadow, and the filled triangle outlines the location of one managed meadow). All panels are adapted from Basemap.at (2020), (C) data source: http://www.basemap.at (last access: April 2020), distributed under the Open Government Data Austrian license CC-BY 4.0.

Müstair 20 years, central Ennstal 20-40 years and Großes Walsertal 35-60 years since abandonment). Before the cessation of management, the abandoned meadows were annually mown and were never used as pastures. The annually mown meadows had an average area of $3049 \mathrm{~m}^{2}$, and the abandoned meadows had an average area of $1366 \mathrm{~m}^{2}$. The sizes of the abandoned and annually mown meadows were not significantly different within each region $(t$ test: central Ennstal, $p=0.295$; Großes Walsertal, $p=0.131$; Müstair, $p=0.323)$.

\subsection{Hoverfly sampling}

We surveyed the number of hoverfly species and individuals once in mid-June and once in mid-August 2015 and finished one round of investigations within $2 \mathrm{~d}$ per month in each region. We started sampling at 10:00 and stopped at 17:00 (all times are in Central European time). In this time period, we found that optimal sampling conditions were a minimum temperature of $20^{\circ} \mathrm{C}$, dry vegetation and sunshine.
In order to increase sampling efficacy, we assessed the number of hoverfly species and individuals by sweep net sampling and an observation plot method (Hussain et al., 2018). Especially the observation plot method has been shown to increase the number of collected species and individuals (Hussain et al., 2018). Syrphid data from the central Ennstal region (Eisenwurzen) for June and August 2015 were provided by Hussain et al. (2017) who used the same sampling methods. Sweep net sampling was performed along three $15 \mathrm{~m}$ long and $2 \mathrm{~m}$ wide transects which were selected in the center of each meadow. Thus, we covered a sampling area of $90 \mathrm{~m}^{2}$. The distances between the transects were $10 \mathrm{~m}$. We used a sweep net consisting of a white cloth $(40 \mathrm{~cm}$ opening diameter, $70 \mathrm{~cm}$ length). We conducted 30 sweeps per transect summing up to 90 sweeps per meadow. The contents of the sweep net were emptied after 30 sweeps and collected insects were killed with ethyl acetate and stored in previously prepared and labeled plastic vials. The sorting of hoverflies was carried out in the laboratory. Hoverflies were stored in glass vials filled with $70 \%$ ethanol. 
In addition to the sweep net method, we applied an observation plot method in which we observed four $2 \mathrm{~m}^{2}$ plots each for $15 \mathrm{~min}$ within every meadow. The plots were distanced 3, 9 and $27 \mathrm{~m}$ from the first plot. The starting plot was selected approximately in the center of each meadow to avoid spillover effects from adjacent habitats. For the collection of single species, we used an insect net $(20 \mathrm{~cm}$ opening diameter, $20 \mathrm{~cm}$ length) mounted on a handle $30 \mathrm{~cm}$ long. Syrphids entering an observation plot were caught and stored in plastic vials. In the laboratory, hoverfly individuals were preserved in glass vials in $70 \%$ ethanol. For analysis, we pooled the individuals caught by sweep netting and those caught during the 15 min observations. Identification was performed using a binocular microscope and identification literature by Stubbs and Falk (1983) and van Veen (2010). For further analysis, we distinguished between hoverflies whose larvae are aphidophagous or non-aphidophagous. We did not consider hoverflies with saprophagous and phytophagous larvae separately due to the low number of species. Larvae of these species are all considered non-aphidophagous. The subdivision into feeding groups is an important aspect because the aphidophagous feeding group most likely contributes to an essential aphid control in nearby arable land. Thus, it is important to test whether the observed meadows can enhance aphidophagous syrphid populations.

\subsection{Vegetation and landscape parameters}

The assessment of plant parameters was carried out in June and August 2015 within $2 \mathrm{~d}$ in each month. We recorded plant parameters within four plots sized $1 \mathrm{~m}^{2}$. As with the plots for syrphid sampling, these plots were situated in the center of the meadows. Within the plots, we identified all plants to the species level and assessed vegetation cover and flower cover. Besides living biomass, vegetation cover included necromass on the ground. For further analysis, we determined the amount of plant species with flowers having a flat corolla (hereafter designated as open nectar flowers, e.g., Ranunculaceae, Asteraceae and Apiaceae) because this flower type is an important food source for hoverflies. Additionally, we measured the surrounding landscape structure from orthophotos in ArcGIS (ArcGIS basemap). Therefore, we measured the percentage of open land (containing, for example, meadows and pastures in the surrounding) and forest (containing, for example, closed forest and hedges) within a $500 \mathrm{~m}$ circle drawn around the center of each meadow. We derived the vegetation and landscape data from the central Ennstal region (Eisenwurzen) for June and August 2015 from Hussain et al. (2017).

\subsection{Statistical analysis}

We used generalized linear models (GLMs) for count data and Poisson error distributions to analyze the effects of management and plant and landscape parameters on hoverfly species and individuals and aphidophagous species and individuals. We included the variable region as a fixed factor in the GLMs. Before testing plant and landscape parameters in a GLM, we ran correlation tests between them. Therefore, we first computed the corr.test function (R package psych; Revelle, 2019) to receive $p$ values and correlation coefficients $(r)$. We found certain correlations between plant and landscape parameters (Table 1). Furthermore, to assess for multicollinearity between predictor variables (management type and vegetation and landscape parameters), we computed the variance inflation factors (VIFs) using the R package car (Fox et al., 2020). Any variables with a VIF greater than 5 were removed from the models. Based on these results, we computed our GLMs. We found that the predictor variables of plant richness, flower cover, vegetation cover and open nectar flowers could have been included in one model (all predictor variables with a VIF less than 3) to evaluate their effects on hoverflies. To investigate the effects of open landscape and forest, we analyzed both factors in a separate model (VIF less than 5). Similarly, according to the VIF output, we also tested the variable management type separately. We accounted for over- and underdispersion of the data by computing the dispersion.test function in $\mathrm{R}$ (Kleiber and Zeileis, 2018). In cases of over- or underdispersion, we corrected the GLMs by using quasi-Poisson error distributions.

To avoid spatial autocorrelation, we performed the Moran's test by applying the Moran.I function (Paradis et al., 2017) for each region individually. Our analysis revealed no spatial autocorrelation between meadows within each region (central Ennstal, $p=0.678$; Großes Walsertal, $p=0.339$; Val Müstair, $p=0.563$ ).

We performed a principal coordinate analysis based on a Bray-Curtis similarity matrix, to evaluate differences in hoverfly species composition between meadow types. As with the GLM, we included the variable region as a fixed factor. Possible significant differences in hoverfly species composition between meadow types were tested with a permutational ANOVA (analysis of variance; PERMANOVA). We calculated $p$ values using 9999 permutations of residuals under a reduced model.

We used version 6.1 .13 of the software PRIMER including PERMANOVA+ (PRIMER-e Ltd., Plymouth, UK) to conduct the principal coordinate analysis and PERMANOVA. We performed all other statistical analyses in $\mathrm{R}$ version 3.5.2 (R Core Team, 2018).

\section{Results}

We collected 175 syrphid individuals belonging to 30 species (Table S2). A total of 25 species with 84 individuals were detected in managed meadows and 18 species with 91 individuals in abandoned meadows. We distinguished between 15 aphidophagous and 12 non-aphidophagous species. 
Table 1. Correlation between plant and landscape parameters. Significant and marginally significant $r$ and $p$ values are pointed out in bold.

\begin{tabular}{|c|c|c|c|c|c|c|c|c|c|c|}
\hline & \multicolumn{2}{|c|}{ Plant species } & \multicolumn{2}{|c|}{ Vegetation cover } & \multicolumn{2}{|c|}{ Flower cover } & \multicolumn{2}{|c|}{ Open flowers } & \multicolumn{2}{|c|}{ Forest cover } \\
\hline & $r$ & $p$ value & $r$ & $p$ value & $r$ & $p$ value & $r$ & $p$ value & $r$ & $p$ value \\
\hline Vegetation cover & -0.22 & 0.375 & & & & & & & & \\
\hline Flower cover & 0.66 & 0.003 & -0.51 & $<0.001$ & & & & & & \\
\hline Open flowers & 0.77 & $<0.001$ & 0.16 & 0.513 & 0.42 & 0.084 & & & & \\
\hline Forest cover & -0.10 & 0.680 & -0.54 & 0.020 & 0.40 & 0.103 & -0.26 & 0.298 & & \\
\hline Open landscape & -0.038 & 0.882 & 0.40 & 0.097 & -0.45 & 0.060 & -0.95 & $<0.001$ & 0.044 & 0.862 \\
\hline
\end{tabular}

Table 2. Generalized linear models (GLMs) showing the effects of plant and landscape parameters on hoverfly species and individuals and on aphidophagous and non-aphidophagous species and individuals. Significant $p$ values are shown in bold, and "df" signifies degrees of freedom.

\begin{tabular}{|c|c|c|c|c|c|c|c|c|c|c|c|}
\hline \multicolumn{6}{|c|}{ Total hoverfly species } & \multicolumn{6}{|c|}{ Total hoverfly individuals } \\
\hline Variables & $\mathrm{df}$ & Estimate & Std. Error & $z$ value & $p$ value & Variables & df & Estimate & Std. Error & $z$ value & $p$ value \\
\hline Intercept & & 0.430 & 0.702 & 0.612 & 0.540 & Intercept & & 2.064 & 1.148 & 1.797 & 0.095 \\
\hline Flower cover & 17 & -0.148 & 0.188 & -0.786 & 0.432 & Flower cover & 17 & -0.215 & 0.325 & -0.663 & 0.518 \\
\hline Plant species & 17 & 0.043 & 0.021 & 2.037 & 0.041 & Plant species & 17 & 0.017 & 0.035 & 0.476 & 0.642 \\
\hline Vegetation cover & 17 & 0.003 & 0.008 & 0.425 & 0.670 & Vegetation cover & 17 & -0.004 & 0.128 & -0.358 & 0.726 \\
\hline Open flowers & 17 & -0.173 & 0.157 & -1.109 & 0.267 & Open flowers & 17 & 0.020 & 0.264 & 0.076 & 0.940 \\
\hline Variables & $\mathrm{df}$ & Estimate & Std. Error & $z$ value & $p$ value & Variables & $\mathrm{df}$ & Estimate & Std. Error & $z$ value & $p$ value \\
\hline Intercept & & 8.809 & 4.795 & 1.837 & 0.066 & Intercept & & 8.922 & 7.780 & 1.147 & 0.269 \\
\hline Open landscape & 17 & -0.062 & 0.048 & -1.277 & 0.201 & Open landscape & 17 & -0.071 & 0.081 & -0.889 & 0.388 \\
\hline Forest cover & 17 & -0.082 & 0.050 & -1.654 & 0.098 & Forest cover & 17 & -0.064 & 0.079 & -0.804 & 0.434 \\
\hline \multicolumn{6}{|c|}{ Aphidophagous hoverfly species } & \multicolumn{6}{|c|}{ Aphidophagous hoverfly individuals } \\
\hline Variables & df & Estimate & Std. Error & $z$ value & $p$ value & Variables & df & Estimate & Std. Error & $z$ value & $p$ value \\
\hline Intercept & & 0.641 & 0.629 & 1.019 & 0.326 & Intercept & & 2.419 & 1.195 & 2.023 & 0.064 \\
\hline Flower cover & 17 & -0.164 & 0.176 & -0.929 & 0.369 & Flower cover & 17 & -0.290 & 0.358 & -0.812 & 0.431 \\
\hline Plant species & 17 & 0.037 & 0.019 & 1.918 & 0.077 & Plant species & 17 & 0.007 & 0.037 & 0.199 & 0.845 \\
\hline Vegetation cover & 17 & 0.001 & 0.007 & 0.088 & 0.931 & Vegetation cover & 17 & -0.009 & 0.013 & -0.682 & 0.507 \\
\hline Open flowers & 17 & -0.202 & 1.142 & -1.426 & 0.177 & Open flowers & 17 & 0.068 & 0.282 & 0.242 & 0.812 \\
\hline Variables & $\mathrm{df}$ & Estimate & Std. Error & $z$ value & $p$ value & Variables & df & Estimate & Std. Error & $z$ value & $p$ value \\
\hline Intercept & & 3.587 & 4 & 0.7 & 6 & Intercept & & 6.968 & 8.653 & 0.8 & 0.433 \\
\hline Open landscape & 17 & -0.013 & 0.047 & -0.279 & 0.784 & Open landscape & 17 & -0.056 & 0.089 & -0.634 & 0.536 \\
\hline Forest cover & 17 & -0.033 & 0.048 & -0.684 & 0.504 & Forest cover & 17 & -0.044 & 0.088 & -0.501 & 0.624 \\
\hline \multicolumn{6}{|c|}{ Non-aphidophagous hoverfly species } & \multicolumn{6}{|c|}{ Non-aphidophagous hoverfly individuals } \\
\hline Variables & $\mathrm{df}$ & Estimate & Std. Error & $z$ value & $p$ value & Variables & df & Estimate & Std. Error & $z$ value & $p$ value \\
\hline Intercept & & -1.850 & 1.424 & -1.299 & 0.216 & Intercept & & -2.345 & 1.840 & -1.274 & 0.225 \\
\hline Flower cover & 17 & -0.639 & 0.425 & -1.504 & 0.157 & Flower cover & 17 & -0.428 & 0.510 & -0.839 & 0.417 \\
\hline Plant species & 17 & 0.113 & 0.052 & 2.161 & 0.050 & Plant species & 17 & 0.131 & 0.067 & 1.951 & 0.073 \\
\hline Vegetation cover & 17 & 0.001 & 0.014 & 0.113 & 0.912 & Vegetation cover & 17 & 0.010 & 0.018 & 0.565 & 0.582 \\
\hline Open flowers & 17 & -0.477 & 0.343 & -1.389 & 0.188 & Open flowers & 17 & -0.677 & 0.434 & -1.559 & 0.143 \\
\hline Variables & $\mathrm{df}$ & Estimate & Std. Error & $z$ value & $p$ value & Variables & df & Estimate & Std. Error & $z$ value & $p$ value \\
\hline Intercept & & 3.587 & 4.684 & 0.766 & 0.459 & Intercept & & 6.968 & 8.653 & 0.805 & 0.433 \\
\hline Open landscape & 17 & -0.013 & 0.047 & -0.279 & 0.784 & Open landscape & 17 & -0.056 & 0.089 & -0.634 & 0.536 \\
\hline Forest cover & 17 & -0.033 & 0.048 & -0.684 & 0.504 & Forest cover & 17 & -0.044 & 0.088 & -0.501 & 0.624 \\
\hline
\end{tabular}


(a)

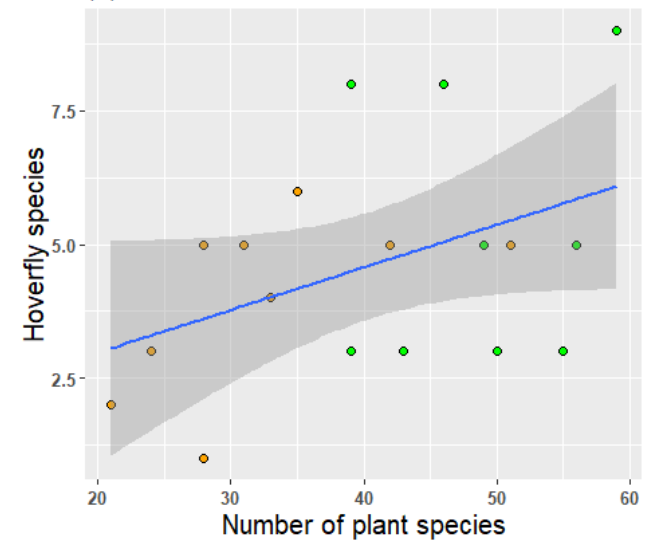

Management Abandoned - Managed

(b)

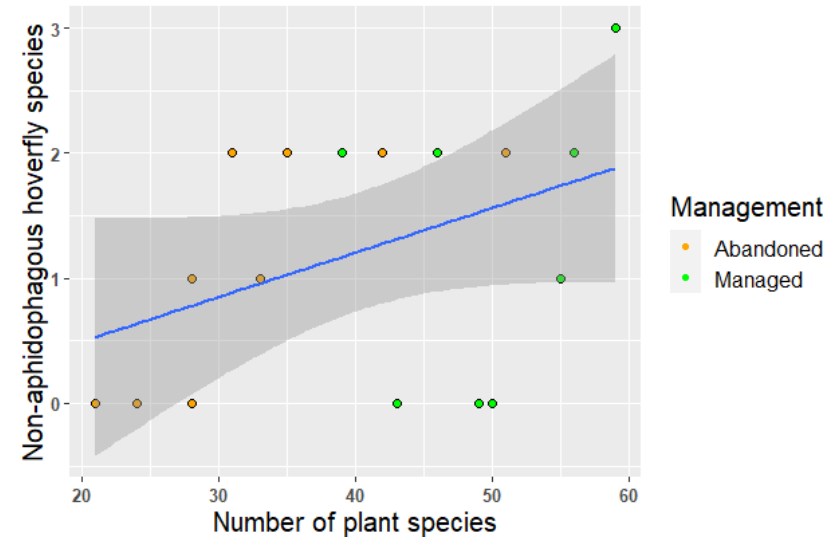

Figure 2. Regression showing (a) the significant relationship between the number of hoverfly species and the number of plant species and (b) the significant relationship between the number of non-aphidophagous species and the number of plant species in managed and abandoned meadows with a $95 \%$ confidence interval.

Six species contributed to more than $75 \%$ of the total individuals. These were Melanostoma mellinum (26.3\%), Sphaerophoria scripta (14.3\%), Lapposyrphus lapponicus (12\%), Melanostoma scalare (11.43\%), Episyrphus balteatus $(7.43 \%)$ and Syritta pipiens (4\%). Five species (Orthonevra geniculata, Parasyrphus annulatus, Platycheirus albimanus, Rhingia borealis and Sphegina sibirica) were only found in abandoned meadows; all other species were found in both meadow types. Three species which could only be identified to the genus level were not assigned to a feeding type. The total number of hoverfly species and individuals did not significantly differ between management types (GLM: $p=0.158$ and $p=0.823$, respectively), and this was also true for the number of aphidophagous and nonaphidophagous species and individuals (GLM: $p=0.430$ and $p=0.130$, respectively). The total number of species significantly increased with the increasing number of plant species (Fig. 2a; Table 2). Similarly, the number of nonaphidophagous species increased with the increasing num-

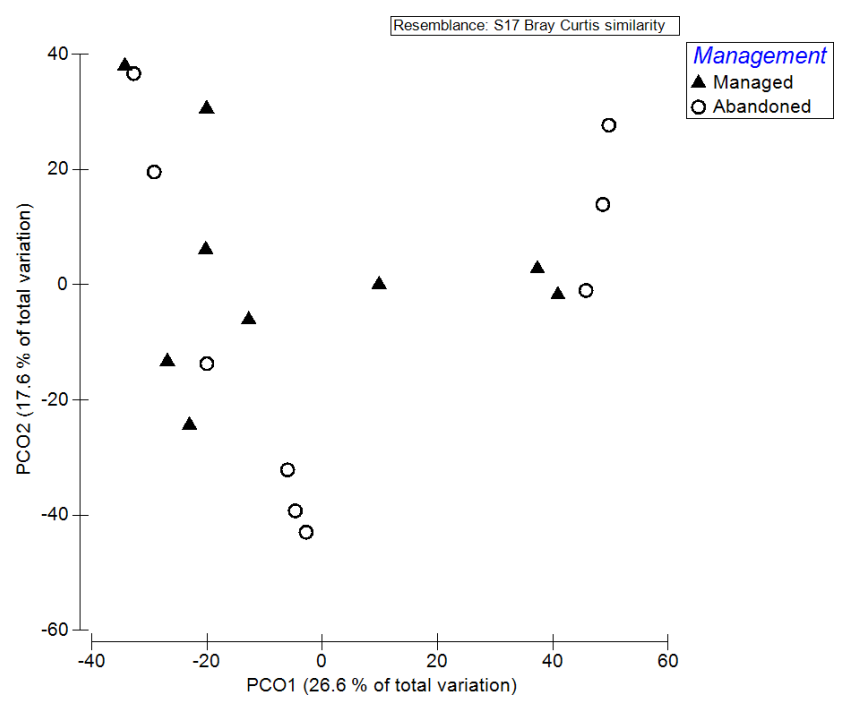

Figure 3. Principal coordinate analysis (PCO) showing hoverfly species composition in managed $(\boldsymbol{\Lambda})$ and abandoned $(\bigcirc)$ meadows.

ber of plant species (Fig. 2b; Table 2). All other recorded plant and landscape parameters did not significantly affect the number of species and individuals of syrphids, and they also had no influence on the number of aphidophagous and non-aphidophagous species and individuals (Table 2). Regarding species composition, there was no difference between both meadow types (PERMANOVA: $p=0.549$ ), which is also graphically represented in the principal coordinate analysis (PCO) (Fig. 3). Regarding plant parameters, the number of vascular plant species was significantly higher in mown meadows (ANOVA: $F=16.31$ and $p<0.001$ ). Flower cover and vegetation cover were higher in mown compared to abandoned meadows (ANOVA: $F=34.3$ and $p<0.001 ; F=6.52$ and $p=0.020$, respectively). A species list of identified plant species in the three study regions is attached in the Supplement (Table S3).

\section{Discussion}

With 46 individuals, Melanostoma mellinum was by far the most abundant hoverfly species in the present study. Furthermore, a higher abundance was made up of the eurytopic species Sphaerophoria scripta, Lapposyrphus lapponicus and Melanostoma scalare. These species are highly migratory, which can lead to a higher abundance in favorable years (Röder, 1990; Speight, 2014).

Regarding the total number of species and individuals, we found no differences between both meadow types. Considering the habitat requirements, most of the observed hoverfly species were eurytopic habitat generalists which use a variety of different habitats (Röder, 1990; Speight, 2014), and it can be assumed that both meadow types fulfilled hoverfly needs by providing similar resources and facilitating suit- 
able microhabitats for their development. The most important factors which a habitat should provide for hoverflies are the availability of suitable floral resources (Hennig and Ghazoul, 2012; Moquet et al., 2018) and the presence of diverse larval habitats (Jauker et al., 2009; Weiner et al., 2014). Similar to the total number of species and abundance, the number of hoverfly species and individuals belonging to the aphidophagous and non-aphidophagous feeding guilds did not differ between meadow types. Especially the abundance of aphidophagous hoverflies is mainly determined by the presence of suitable aphid hosts (Almohamad et al., 2009). There is a very important contribution by Kök et al. (2020) which focused on the tritrophic relationships between plants, aphids and hoverflies. They found that plant species host different aphid species which in turn are a suitable prey for the larvae of aphidophagous hoverfly species like Sphaerophoria scripta and Episyrphus balteatus. This suggests that the choice of the habitats is mainly driven by these relationships.

Consistent with the lack of differences of species richness and abundance, we found a similar species composition in both meadow types. Only five species were confined to abandoned meadows and all other species were found in both meadow types. In contrast to, for example, bumblebees who have to provide pollen for their offspring, adult hoverflies are highly mobile, free in their dispersal (Meyer et al., 2009; Sutherland et al., 2001) and able to track suitable flower resources among a wide range of habitats (Jauker et al., 2009; Meyer et al., 2017).

The diversity of vascular plants turned out to be an important factor for hoverflies. Both the number of total hoverfly species and the number of non-aphidophagous species increased with an increasing plant richness. This indicates that a high variety of plant resources is most beneficial in maintaining hoverfly diversity in these grasslands (e.g., Meyer et al., 2009). The status of a high plant richness can only be preserved through regular extensive management. Grassland abandonment results in a decrease in plant richness (Pykälä et al., 2005) and consequently would have negative effects on hoverfly richness.

Surprisingly, we found no relationship between hoverflies and flower cover, contradicting the results of other studies (Meyer et al., 2009; Frank, 1999; Fründ et al., 2010; Power et al., 2016). However, our results are in line with those of Hussain et al. (2017) who reported that flower cover had no effect on syrphid richness and abundance. They mainly attributed this result to the presence of more flowers which have a deep, non-accessible corolla (e.g., Salvia pratensis and Rhinanthus minor), which is presumably also a good explanation for the findings in our study. For example, only a few syrphid species from the genus Rhingia developed specialized mouth parts to access the hidden nectar (Speight, 2014). However, with the exception of Rhingia borealis, these species were absent in our meadows. Another explanation for the missing relationship between flowers and hoverflies could be that hoverflies also feed on the honeydew from aphids that can be unrelated to the abundance of suitable flowers (van Rijn et al., 2013).

\section{Conclusion}

Although there was no overall effect of abandonment on syrphid richness, abundance and composition in the present study, plant richness turned out to be an important determinant for syrphid diversity in the investigated meadows, confirming also the results of other studies (e.g., Meyer et al., 2009; Hussain et al., 2017). In turn, this high plant richness can only be maintained by a regular extensive management. However, abandoned meadows also have the potential to contribute to a high hoverfly diversity in mountainous grasslands since some species were only found in abandoned meadows. Our results suggest that the maintenance of a heterogenous landscape containing both regularly mown and abandoned meadows is most beneficial for the conservation of hoverfly diversity in mountainous grasslands.

Data availability. The data used in this study are provided in the Supplement.

Supplement. The supplement related to this article is available online at: https://doi.org/10.5194/we-20-143-2020-supplement.

Author contributions. RW conducted field work, analyzed the data and wrote the paper. RIH and DB sampled and identified collected syrphids. RIH contributed hoverfly data from central Ennstal, and $\mathrm{JK}$ and $\mathrm{AB}$ recorded plant parameters. AA, JGZ and TF were the project leaders who designed and developed the "Healthy Alps" project. All authors reviewed the paper.

Competing interests. The authors declare that they have no conflict of interest.

Acknowledgements. We want to thank all the farmers and land owners for their cooperation and for providing their meadows for our investigations.

Review statement. This paper was edited by Matthias Foellmer and reviewed by three anonymous referees.

Financial support. This research has been supported by the Austrian Academy of Sciences (project: Healthy Alps). 


\section{References}

Almohamad, R., Verheggen, F. J., and Haubruge, E.: Searching and oviposition behavior of aphidophagous hoverflies (Diptera: Syrphidae): a review, Biotechnol. Agron. Soc. Environ., 13, 467481, 2009.

Azcárate, F. M. and Peco, B.: Abandonment of grazing in a mediterranean grassland area: consequences for ant assemblages, Insect Conserv. Diver., 5, 279-288, https://doi.org/10.1111/j.17524598.2011.00165.x, 2011.

Basemap.at: Verwaltungsgrundkarte von Österreich, available at: https://www.basemap.at, last access: April 2020.

Baur, B., Cremene, C., Groza, G., Rakosy, L., Schileyko, A. A., Baur, A., Stoll, P., and Erhardt, A.: Effects of abandonment of subalpine hay meadows on plant and invertebrate diversity in Transylvania, Romania, Biol. Conserv., 132, 261-273, https://doi.org/10.1016/j.biocon.2006.04.018, 2006.

Bonari, G., Fajmon, K., Malenovský, I., Zelený, D., Holuša, J., Jongepierová, I., Kočárek, P., Ondřej, K., Uřičář, J., and Chytrý, M.: Management of semi-natural grasslands benefiting both plant and insect diversity: The importance of heterogeneity and tradition, Agric. Ecosyst. Environ., 246, 243-252, https://doi.org/10.1016/j.agee.2017.06.010, 2017.

Burel, F.: Ecological consequences of land abandonment on carabid beetles distribution in two contrasted grassland areas, Options Méditerranéennes, 15, 111-119, 1991.

Burgio, G. and Sommagio, D.: Syrphids as landscape bioindicators in Italian agroecosystems, Agr. Ecosyst. Environ., 120, 416-422, https://doi.org/10.1016/j.agee.2006.10.021, 2007.

Chemini, C. and Rizzoli, A.: Land use change and biodiversity conservation in the Alps, J. Mt. Ecol., 7, 1-7, 2003.

Chytrý, M., Dražil, T., Hájek, M., Kalníková, V., Preislerová, Z., Šibík, J., Ujházy, K., Axmanová, I., Bernátová, D., Blanár, D., Dančák, M., Dřevojan, P., Fajmon, K., Galvánek, D., Hájková, P., Herben, T., Hrivnák, R., Janeček, ک̌ ., Janišová, M., Jiráská, Š., Kliment, J., Kochjarová, J., Lepš, J., Leskovjanská, A., Merunková, K., Mládek, J., Slezák, M., Šeffer, J., Šefferová, V., Škodová, I., Uhlîrová, J., Ujházyová, M., and Vymazalová, M.: The most species-rich plant communities in the Czech Republic and Slovakia (with new world records), Preslia, 87, 217-278, 2015.

Cremene, C., Groza, G., Rakosy, L., Schileyko, A. A., Baur, A., Erhardt, A., and Baur, B.: Alterations of steppe-like grasslands in Eastern Europe: a threat to regional biodiversity hotspots, Conserv. Biol., 19, 1606-1618, https://doi.org/10.1111/j.15231739.2005.00084.x, 2005.

Diemer, M., Oetiker, K., and Billeter, R.: Abandonment alters community composition and canopy structure of Swiss calcareous fens, Appl. Veg. Sci., 4, 237-246, https://doi.org/10.1111/j.1654109X.2001.tb00492.x, 2001.

Fox, J., Weisberg, S., Adler, D., Bates, D., Baud-Bovy, G., Ellison, S., Firth, D., Friendly, M., Gorjanc, G., Graves, S., Heiberger, R., Krivitsky, P., Laboissiere, R., Maechler, M., Monette, G., Murdoch, D., Nilsson, H., Ogle, D., Ripley, B., Venables, W., Walker, S., Winsemius, D., and Zeileis, A.: car: Companion to applied regression, R-package 3.0-8, 2020.

Frank, T.: Density of adult hoverflies (Diptera, Syrphidae) in sown weed strips and adjacent fields, J. Appl. Ent., 123, 351-355, https://doi.org/10.1046/j.1439-0418.1999.00383.x, 1999.
Fründ, J., Linsenmair, K. E., and Blüthgen, N.: Pollinator diversity and specialization in relation to flower diversity, Oikos, 119, 1581-1590, https://doi.org/10.1111/j.1600-0706.2010.18450.x, 2010.

Galvánek, D. and Lepš, J.: Changes of species richness pattern in mountain grasslands: abandonment versus restoration, Biodivers. Conserv., 17, 3241-3253, https://doi.org/10.1007/s10531-0089424-2, 2008.

Gittings, T., O'Halloran, J., Kelly, T., and Giller, P. S.: The contribution of open spaces to the maintenance of hoverfly (Diptera, Syrphidae) biodiversity in Irish plantation forests, Forest Ecol. Manag., 237, 290-300, https://doi.org/10.1016/j.foreco.2006.09.052, 2006.

Graf, R., Müller, M., Korner, P., Jenny, M., and Jenni, L.: $20 \%$ loss of unimproved farmland in 22 years in the Engadin, Swiss Alps, Agric. Ecosyst. Environ., 185, 48-58, https://doi.org/10.1016/j.agee.2013.12.009, 2014.

Habel, J. C., Dengler, J., Janišová, M., Török, P., Wellstein, C., and Wiezik, M.: European grassland ecosystems: threatened hotspots of biodiversity, Biodivers. Conserv., 22, 2131-2138, https://doi.org/10.1007/s10531-013-0537-x, 2013.

Haenke, S., Scheid, B., Schaefer, M., Tscharntke, T., and Thies, C.: Increasing syrphid fly diversity and density in sown flower strips within simple vs. complex landscapes, J. Appl. Ecol., 46, 11061114, https://doi.org/10.1111/j.1365-2664.2009.01685.x, 2009.

Hansson, M. and Fogelfors, H.: Management of a seminatural grassland; results from a 15-year-old experiment in southern Sweden, J. Veg. Sci., 11, 31-38, https://doi.org/10.2307/3236772, 2000.

Heijcman, M., Hejcmanová, V., Pavlů, V., and Beneš, J.: Origin and history of grasslands in Central Europe - a review, Grass Forage Sci., 68, 345-363, https://doi.org/10.1111/gfs.12066, 2013.

Hennig, E. I. and Ghazoul, J.: Pollinating animals in the urban environment, Urban Ecosyst., 15, 149-166, https://doi.org/10.1007/s11252-011-0202-7, 2012.

Hinojosa, L., Napoléone, C., Moulery, M., and Lambin, E. F.: The "mountain effect" in the abandonment of grasslands: Insights from the French Southern Alps, Agric. Ecosyst. Environ., 221, 115-124, https://doi.org/10.1016/j.agee.2016.01.032, 2016.

Hülber, K., Moser, D., Sauberer, N., Maas, B., Staudinger, M., Grass, V., Wrbka, T., and Willner, W.: Plant species richness decreased in semi-natural grasslands in the Biosphere Reserve Wienerwald, Austria, over the past two decades, despite agrienvironmental measures, Agr. Ecosyst. Environ., 243, 10-18, https://doi.org/10.1016/j.agee.2017.04.002, 2017.

Hussain, R. I., Walcher, R., Brandl, D., Jernej, I., Arnberger, A., Zaller, J. G., and Frank, T.: Influence of abandonment on syrphid assemblages in mountainous meadows, J. Appl. Entomol., 142, 450-456, https://doi.org/10.1111/jen.12482, 2017.

Hussain, R. I., Walcher, R., Brandl, D., Arnberger, A., Zaller, J. G., and Frank, T.: Efficiency of two methods of sampling used to assess the abundance and species diversity of adult Syrphidae (Diptera) in mountainous in the Austrian and Swiss Alps, Eur. J. Entomol., 115, 150-156, https://doi.org/10.14411/eje.2018.014, 2018.

Jauker, F. and Wolters, V.: Hoverflies are efficient pollinators of oilseed rape, Oecologia, 156, 819-823, https://doi.org/10.1007/s00442-008-1034-x, 2008. 
Jauker, F., Diekötter, T., Schwarzbach, F., and Wolters, V.: Pollinator dispersal in an agricultural matrix: opposing responses of wild bees and hoverflies to landscape structure and distance from main habitat, Landscape Ecol., 24, 547-555, https://doi.org/10.1007/s10980-009-9331-2, 2009.

Jovičić, S., Burgio, G., Diti, I., Krašić, D., Markov, Z., Radenković, S., and Vujić, A.: Influence of landscape structure and land use on Merodon and Cheilosia (Diptera: Syrphidae): contrasting responses of two genera, J. Insect. Conserv., 21, 53-64, https://doi.org/10.1007/s10841-016-9951-1, 2017.

Kleiber, C. and Zeileis, A.: AER: Applied Econometrics with R, R package version 1.2-6, 2018.

Kök, S., Tomanović, Z., Nedeljković, Z., Şenal, D., and Kasap, İ.: Biodiversity of the natural enemies of aphids (Hemiptera: Aphididae) in Northwest Turkey, Phytoparasitica, 48, 51-61, https://doi.org/10.1007/s12600-019-00781-8, 2020.

Leroy, P. D., Almohamad, R., Attia, S., Capella, Q., Verheggen, F. J., Haubruge, E., and Francis, F.: Aphid honeydew: An arrestant and a contact kairomone for Episyrphus balteatus (Diptera: Syrphidae) larvae and adults, Eur. J. Entomol., 111, 237-242, 2014.

Maurer, K., Weyand, A., Fischer, M., and Stöcklin, J.: Old cultural traditions, in addition to land use and topography, are shaping plant diversity of grasslands in the Alps, Biol. Conserv., 130, 438-446, https://doi.org/10.1016/j.biocon.2006.01.005, 2006.

McGinlay, J., Gowing, D. J. G., and Budds, J.: The threat of abandonment in socio-ecological landscapes: Farmers' motivations and perspectives on high nature value grassland conservation, Environ. Sci. Policy, 69, 39-49, https://doi.org/10.1016/j.envsci.2016.12.007, 2017.

Meyer, B., Jauker, F., and Steffan-Dewenter, I.: Contrasting resource-dependent responses of hoverfly richness and density to landscape structure, Basic Appl. Ecol., 10, 178-186, https://doi.org/10.1016/j.baae.2008.01.001, 2009.

Meyer, S., Unternährer, D., Arlettaz, R., Humbert, J.-Y., and Menz, M. H. M.: Promoting diverse communities of wild bees and hoverflies requires a landscape approach to managing meadows, Agr. Ecosyst. Environ., 239, 376-384, https://doi.org/10.1016/j.agee.2017.01.037, 2017.

Moog, D., Poschlod, P., Kahmen, S., and Schreiber, K. F.: Comparison of species composition between different grassland management treatments after 25 years, Appl. Veg. Sci., 5, 99-106, https://doi.org/10.1111/j.1654-109X.2002.tb00539.x, 2002.

Moquet, L., Laurent, E., Bacchetta, R., and Jacquemart, A-L.: Conservation of hoverflies (Diptera, Syrphidae) requires complementary resources at the landscape and local scales, Insect Conserv. Diver., 11, 72-87, https://doi.org/10.1111/icad.12245, 2018.

Öckinger, E., Eriksson, A. K., and Smith, H. G.: Effects of grassland abandonment, restoration and management on butterflies and vascular plants, Biol. Conserv., 133, 291-300, https://doi.org/10.1016/j.biocon.2006.06.009, 2006.

Paradis, E., Blomberg, S., Bolker, B., Brown, J., Claude, J., Sien Cuong, H., Desper, R., Didier, G., Durand, B., Dutheil, J., Ewing, R. J., Gascuel, O., Guillerme, T., Heibl, C., Ives, A., Jones, B., Krah, F., Lawson, D., Lefort, V., Legendre, P., Lemon, J., Marcon, E., McCloskey, R., Nylander, J., Opgen-Rhein, J., Popescu, A-A., Royer-Carenzi, M., Schliep, K., Strimmer, K., and de Vienne, D.: ape: Analysis of phylogenetics and evolution, R Package version $5.0,2017$
Poschlod, P. and WallisDeVries, M. F.: The historical and socioeconomic perspective of calcareous grasslands - lessons from the distant and recent past, Biol. Conserv., 104, 361-376, https://doi.org/10.1016/S0006-3207(01)00201-4, 2002.

Power, F. E., Jackson, Z., and Stout J. C.: Organic farming and landscape factors affect abundance and richness of hoverflies (Diptera, Syrphidae) in grasslands, Insect Conserv. Diver., 9, 244-253, https://doi.org/10.1111/icad.12163, 2016.

Pykälä, J., Luoto, M., Heikkinen, R. K., and Kontula, T.: Plant species richness and persistence of rare plants in abandoned semi-natural grasslands in northern Europe, Basic Appl. Ecol., 6, 25-33, https://doi.org/10.1016/j.baae.2004.10.002, 2005.

Rader, R., Bartomeus, I., Garibaldi, L. A., Garratt, M. P. D., Howlett, B. G., Winfree, R., Cunningham, S. A., Mayfield, M. M., Arthur, A. D., Andersson, G. K. S., Bommarco, R., Brittain, C., Carvalheiro, L. G., Chacoff, N. P., Entling, M. H., Foully, B., Freitas, B. M., Gemmill-Herren, B., Ghazoul, J., Griffin, S. R., Gross, C. L., Herbertsson, L., Herzog, F., Hipólito, J., Jaggar, S., Jauker, F., Klein, A.-M., Kleijn, D., Krishnan, S., Lemos, C. Q., Lindström, S. A. M., Mandelik, Y., Monteiro, V. M., Nelson, W., Nilsson, L., Pattemore, D. E., Pereira, N. de O., Pisanty, G., Potts, S. G., Reemer, M., Rundlöf, M., Sheffield, C. S., Scheper, J., Schüepp, C., Smith, H. G., Stanley, D. A., Stout, J. C., Szentgyörgyi, H., Taki, H., Vergara, C. H., Viana, B. F., and Woyciechowski, M.: Non-bee insects are important contributors to global crop pollination, P. Natl. Acad. Sci. USA, 113, 146-151, https://doi.org/10.1073/pnas.1517092112, 2016.

R Core Team: R: A language and environment for statistical computing (Ver. 3.5.2), available at: https://www.R-project.org/, last access: May 2018.

Revelle, W.: psych: Procedures for psychological, psychometric and personality research, R package version 1.8.12, 2019.

Rey Benayas, J. M., Martins, A., Nicolau, J. M., and Schulz, J.: Abandonment of agricultural land: an overview of drivers and consequences, CAB Reviews, 2, 1-14, https://doi.org/10.1079/PAVSNNR20072057, 2007.

Röder, G.: Biologie der Schwebfliegen Deutschlands (Diptera: Syrphidae), Erna Bauer-Verlag, Keltern-Weiler, Germany, 1990.

Schirmel, J., Mantilla-Contreras, J., Blindow, I., and Fartmann, T.: Impacts of succession and grass encroachment on heathland Orthoptera, J. Insect. Conserv., 15, 633-642, https://doi.org/10.1007/s10841-010-9362-7, 2011.

Speight, M. C. D.: Species accounts of European Syrphidae (Diptera), 2014, Syrph the Net, the database of European Syrphidae, Dublin, Ireland, 2014.

Strijker, D.: Marginal lands in Europe - causes of decline, Basic Appl. Ecol., 6, 99-106, https://doi.org/10.1016/j.baae.2005.01.001, 2005.

Stubbs, A. and Falk, A. E.: British hoverflies: An illustrated identification guide, British Entomological and Natural History Society, London, 1983.

Sutherland, J. P., Sullivan, M. S., and Poppy, G. M.: Distribution and abundance of aphidophagous hoverflies (Diptera: Syrphidae) in wildflower patches and field margin habitats, Agric. For. Entomol., 3, 57-64, https://doi.org/10.1046/j.14619563.2001.00090.x, 2001.

Tasser, E. and Tappeiner, U.: Impact of land use changes on mountain vegetation, Appl. Veg. Sci., 5, 173-184, https://doi.org/10.1111/j.1654-109X.2002.tb00547.x, 2002. 
Tasser, E., Walde, J., Tappeiner, U., Teutsch, A., and Noggler, W.: Land-use changes and natural reforestation in the Eastern Central Alps, Agric. Ecosyst. Environ., 118, 115-129, https://doi.org/10.1016/j.agee.2006.05.004, 2007.

van Rijn, P. C. J., Kooijman, J., and Wäckers, F. L.: The contribution of floral resources and honeydew to the performance of predatory hoverflies (Diptera: Syrphidae), Biol. Control, 67, 3238, https://doi.org/10.1016/j.biocontrol.2013.06.014, 2013.

van Veen, M. P. V.: Hoverflies of Northwest Europe: Identification keys to the Syrphidae, KNNV Publishing, Utrecht, 2010.

Walcher, R., Karrer, J., Sachslehner, L., Bohner, A., Pachinger, B., Brandl, D., Zaller, J. G., Arnberger, A., and Frank, T.: Diversity of bumblebees, heteropteran bugs and grasshoppers maintained by both: abandonment and extensive management of mountain meadows in three regions across the Austrian and Swiss Alps, Landscape Ecol., 32, 1937-1951, https://doi.org/10.1007/s10980-017-0556-1, 2017.
Weiner, C. N., Werner, M., Linsenmair, K. E., and Blüthgen, N.: Land-use impacts on plant-pollinator networks: interaction strength and specialization predict pollinator declines, Ecology, 95, 466-474, https://doi.org/10.1890/13-0436.1, 2014.

Wiezik, M., Svitok, M., Wieziková, A., and Dovčiak, M.: Shrub encroachment alters composition and diversity of ant communities in abandoned grasslands of western Carpathians, Biodivers. Conserv., 22, 2305-2320, https://doi.org/10.1007/s10531-013-0446z, 2013. 